\title{
Air pollution and hospital admissions for respiratory conditions in Rome, Italy
}

\author{
D. Fusco*, F. Forastiere*, P. Michelozzi*, T. Spadea*, B. Ostro\#, M. Arcà*, C.A. Perucci*
}

Air pollution and hospital admissions for respiratory conditions in Rome, Italy. D. Fusco, F. Forastiere, P. Michelozzi, T. Spadea, B. Ostro, M. Arcà, C.A. Perucci. (C) ERS Journals Ltd 2001.

ABSTRACT: Most of the evidence regarding the association between particulate air pollution and emergency room visits or hospital admissions for respiratory conditions and asthma comes from the USA. European time-series analyses have suggested that gaseous air pollutants are important determinants of acute hospitalization for respiratory conditions, at least as important as particulate mass. The association between daily mean levels of suspended particles and gaseous pollutants (sulphur dioxide, nitrogen dioxide, carbon monoxide, ozone) was examined. The daily emergency hospital admissions for respiratory conditions in the metropolitan area of Rome during 1995-1997 were also recorded.

Daily counts of hospital admissions for total respiratory conditions (43 admissions $\cdot$ day $\left.^{-1}\right)$, acute respiratory infections including pneumonia $\left(18 \cdot\right.$ day $\left.^{-1}\right)$, chronic obstructive pulmonary disease (COPD) $\left(13 \cdot \mathrm{day}^{-1}\right)$, and asthma $\left(4.5 \cdot \mathrm{day}^{-1}\right)$ among residents of all ages and among children ( $0-14$ yrs) were analysed. The generalized additive models included spline smooth functions of the day of study, mean temperature, mean humidity, influenza epidemics, and indicator variables for day of the week and holidays.

Total respiratory admissions were significantly associated with same-day level of $\mathrm{NO}_{2}\left(2.5 \%\right.$ increase per interquartile range (IQR) change, $\left.22.3 \mu \mathrm{g} \cdot \mathrm{m}^{-3}\right)$ and $\mathrm{CO}(2.8 \%$ increase per IQR, $1.5 \mathrm{mg} \cdot \mathrm{m}^{-3}$ ). No effect was found for particulate matter and $\mathrm{SO}_{2}$, whereas $\mathrm{O}_{3}$ was associated with admissions only among children (lag 1, 5.5\% increase per IQR, $23.9 \mu \mathrm{g} \cdot \mathrm{m}^{3}$ ). The effect of $\mathrm{NO}_{2}$ was stronger on acute respiratory infections (lag $0,4.0 \%$ increase) and on asthma among children (lag 1, 10.7\% increase). The admissions for all ages for asthma and COPD were associated only with same-day level of $\mathrm{CO}(5.5 \%$ and $4.3 \%$ increase, respectively). Multipollutant models confirmed the role of $\mathrm{CO}$ on all respiratory admissions, including asthma and COPD, and that of $\mathrm{NO}_{2}$ on acute respiratory infections. Among children, $\mathrm{O}_{3}$ remained a strong indicator of acute respiratory infections.

Carbon monoxide and photochemical pollutants (nitrogen dioxide, ozone) appear to be determinants of acute respiratory conditions in Rome. Since carbon monoxide and nitrogen dioxide are good indicators of combustion products from traffic related sources, the detected effect may be due to unmeasured fine and ultrafine particles. Eur Respir J 2001; 17: 1143-1150.
*Agency for Public Health, Rome, Italy, ${ }^{\sharp}$ California Environmental Protection Agency, Oakland, CA, USA.

Correspondence: F. Forastiere

Agency for Public Health

Lazio Region

Via Santa Costanza 53

00198 Roma

Italy

Fax: 390651686463

Keywords: Air pollution

hospital admissions

respiratory disease

time-series

Received: January 202000

Accepted after revision February 2 2001
Daily levels of air pollutants have been associated with increased daily mortality, and time-series studies in North America have indicated that particles and ozone are related to emergency hospital admissions for respiratory conditions $[1-3]$. Nitrogen dioxide and carbon monoxide, however, were not considered in most of the initial studies. Additional investigations $[4,5]$, including studies in European cities [6-8] and Australia [9], have suggested that not only $\mathrm{O}_{3}$, but also other gaseous air pollutants have a role, at least as important as particulate matter in explaining variations in respiratory emergency admissions. BURNETT et al. [5] have underlined the importance of considering all available air pollution measures to assess the health effects of a single pollutant, even though there are difficulties in separating the effects of particles from those of various gases, the gases themselves (especially $\mathrm{NO}_{2}$ and $\mathrm{CO}$ ) may be surrogates for fine and ultrafine particles.

Air pollution in Rome originates mostly from motor vehicle traffic. As a result, concentrations of $\mathrm{CO}, \mathrm{NO}_{2}, \mathrm{O}_{3}$ and airborne particles are generally high, but with different seasonal patterns. Sulphur dioxide levels are usually low. Previously, an association between daily total mortality and $\mathrm{NO}_{2}$ and particles levels in the central area of the city was reported. These associations were consistent in magnitude with other observations in the North American and European setting [10]. In the current study, the association between daily mean levels of particulate matter and gaseous pollutants $\left(\mathrm{SO}_{2}, \mathrm{NO}_{2}, \mathrm{CO}, \mathrm{O}_{3}\right)$ and daily hospital admissions for respiratory conditions during 1995-1997 was examined. A separate paper will consider air pollution and cardiovascular 
admissions. The present study evaluated overall as well as cause-specific respiratory conditions, with a specific interest in acute respiratory infections (including pneumonia). These represent a common cause of exacerbation of pre-existing chronic respiratory diseases in adults and occur relatively frequently in children with and without asthma. The analysis was conducted among residents of all ages, but also focused on subjects in the range $0-14$ yrs.

\section{Methods}

\section{Air pollution and weather data}

A network of fixed air quality monitoring stations (covering $\sim 3$ million inhabitants) operates in Rome under the Regional Department of Environment. Five stations, located in densely populated areas within the central city, continuously collect hourly data on $\mathrm{SO}_{2}$ levels (ultraviolet fluorescence), $\mathrm{NO}_{2}$ (chemiluminescence) and $\mathrm{CO}$ (infrared photometry); three of the five monitors also collect hourly data on $\mathrm{O}_{3}$ (ultraviolet photometry) and bihourly data on particles. Data on particles with a $50 \%$ cut-off aerodynamic diameter of $10 \mu \mathrm{m}$ (PM10) concentrations were not available for the study period. Suspended particles were continuously monitored using a low-volume air sampler (flow rate at $25 \mathrm{~L} \cdot \mathrm{min}^{-1}$ ) with an open-face inlet and $\beta$-ray atomic absorption. Investigations in Rome with a gravimetric method to measure PM10 and total suspended particulates, showed a higher ratio of PM10 and total suspended particulates $(0.70-0.80)$ than the ratios detected in North America [11]. This is presumably due to both the low-volume sampling and to the peculiar geometry of the open-face inlet that produced a higher efficiency for small size particulate fractions. Furthermore, detailed examinations with electron microscopy of the relative size of the particles sampled with the Italian instrument indicated that the actual particle fraction measured is $<13 \mu \mathrm{m}$.

The daily air pollution data (24-h integrated measure for particles, $\mathrm{SO}_{2}, \mathrm{NO}_{2}$, and $\mathrm{CO}$; the mean 08:00 $\mathrm{h}-16: 00 \mathrm{~h}$ for $\mathrm{O}_{3}$ ) were collected from the five population oriented fixed monitors. For each day, the data from the available monitors were averaged to compute a city mean to match the daily hospital admissions data. During the study period (January 1, 1995 - October 31, 1997), data were available from all the monitors for $89.9 \%$ of the days for particles, $99.5 \%$ for $\mathrm{SO}_{2}, 99.6 \%$ for $\mathrm{NO}_{2}, 99.8 \%$ for $\mathrm{CO}$, and $95.6 \%$ for $\mathrm{O}_{3}$. Since some values for a particular monitor and a particular pollutant were missing, this data was imputed before computing city means using regression models based on the other monitors' values; the estimated values were used only if the goodness of fit $\left(\mathrm{R}^{2}\right)$ of the regression models was $>0.60$. After this procedure, the percentage of missing values was $2.6 \%$ for particles, whereas there were no missing data for the other pollutants. The spatial within-day variability for the different pollutants was assessed by calculating pollutant-specific correlation coefficients among the various fixed-monitors. The highest correlations were found for gases $\left(\mathrm{O}_{3}\right.$ : $0.66-0.89 ; \mathrm{CO}: 0.60-0.86 ; \mathrm{NO}_{2}$ : $\left.0.66-0.79 ; \mathrm{SO}_{2}: 0.50-0.77\right)$, whereas particles had the lowest values $(0.22-0.30)$. Mean daily temperature $\left({ }^{\circ} \mathrm{C}\right)$ and relative humidity $(\%)$ were available from the local weather station located in the central area.

Table 1 summarizes the environmental variables and table 2 shows the Pearson correlation coefficients for all year and by season (cold season: OctoberMarch; warm season: April-September). Particles and $\mathrm{NO}_{2}$ did not follow a seasonal pattern and were not correlated with temperature; $\mathrm{SO}_{2}$ and $\mathrm{CO}$ tended

Table 1. - Summary of environmental variables and daily hospital admissions data in Rome, 1995-1997

\begin{tabular}{|c|c|c|c|c|c|c|}
\hline \multirow[t]{2}{*}{ Variable } & \multirow[t]{2}{*}{ ICD No. } & \multirow[t]{2}{*}{ Mean \pm SD } & \multicolumn{3}{|c|}{ Percentiles } & \multirow[t]{2}{*}{ IQR } \\
\hline & & & 25 th & 50 th & 75 th & \\
\hline \multicolumn{7}{|l|}{ Environmental variables* } \\
\hline Temperature ${ }^{\circ} \mathrm{C}$ & & $16.8 \pm 6.5$ & 11.6 & 16.8 & 22.3 & 10.7 \\
\hline Humidity \% & & $59.6 \pm 12.4$ & 51.0 & 59.0 & 69.0 & 18.0 \\
\hline Particles $\mu \mathrm{g} \cdot \mathrm{m}^{-3 * *}$ & & $66.4 \pm 21.2$ & 55.3 & 66.5 & 78.3 & 23.0 \\
\hline $\mathrm{SO}_{2} \mu \mathrm{g} \cdot \mathrm{m}^{-3}$ & & $9.1 \pm 5.8$ & 5.1 & 7.9 & 12.0 & 6.9 \\
\hline $\mathrm{NO}_{2} \mu \mathrm{g} \cdot \mathrm{m}^{-3}$ & & $86.7 \pm 16.2$ & 74.9 & 86.1 & 97.2 & 22.3 \\
\hline $\mathrm{CO} \mathrm{mg} \cdot \mathrm{m}^{-3}$ & & $3.6 \pm 1.2$ & 2.8 & 3.5 & 4.3 & 1.5 \\
\hline $\mathrm{O}_{3} \mu \mathrm{g} \cdot \mathrm{m}^{-3}$ & & $27.0 \pm 17.3$ & 13.3 & 24.0 & 37.2 & 23.9 \\
\hline \multirow{2}{*}{\multicolumn{7}{|c|}{$\begin{array}{l}\text { Hospital admissions data } \\
\text { All ages }\end{array}$}} \\
\hline & & & & & & \\
\hline Respiratory conditions & $460-519$ & $43.1 \pm 13.3$ & 34.0 & 43.0 & 52.0 & 18.0 \\
\hline Acute respiratory infections & $460-466 ; 480-486$ & $18.0 \pm 6.8$ & 13.0 & 17.0 & 22.0 & 9.0 \\
\hline Asthma & 493 & $4.5 \pm 2.8$ & 2.0 & 4.0 & 6.0 & 4.0 \\
\hline COPD & $490-492 ; 494-496$ & $13.0 \pm 5.5$ & 9.0 & 13.0 & 16.0 & 7.0 \\
\hline \multicolumn{7}{|l|}{$0-4$ yrs } \\
\hline Respiratory conditions & $460-519$ & $11.3 \pm 5.8$ & 7.0 & 11.0 & 15.0 & 8.0 \\
\hline Acute respiratory infections & $460-466 ; 480-486$ & $8.4 \pm 4.7$ & 5.0 & 8.0 & 11.0 & 6.0 \\
\hline Asthma & 493 & $1.8 \pm 1.7$ & 1.0 & 1.0 & 3.0 & 2.0 \\
\hline
\end{tabular}

*24-h mean for all environmental variables except ozone $\left(\mathrm{O}_{3}\right)$ which is 8-h mean; **suspended particles with a cut-off point at $\sim 13 \mu \mathrm{m} . \mathrm{SO}_{2}$ : sulphur dioxide; $\mathrm{NO}_{2}$ : nitrogen dioxide; $\mathrm{CO}$ : carbon monoxide; COPD: chronic obstructive pulmonary disease; ICD: International Classification of Diseases; IQR: interquartile range. 
Table 2. - Pearson correlation coefficients among environmental variables, Rome 1995-1997

\begin{tabular}{|c|c|c|c|c|c|c|}
\hline & Temperature & Humidity & Particles & $\mathrm{SO}_{2}$ & $\mathrm{CO}$ & $\mathrm{NO}_{2}$ \\
\hline \multicolumn{7}{|l|}{ Whole year } \\
\hline Humidity \% & -0.21 & & & & & \\
\hline Particles $\mu \mathrm{g} \cdot \mathrm{m}^{-3 *}$ & 0.00 & 0.07 & & & & \\
\hline $\mathrm{SO}_{2} \mu \mathrm{g} \cdot \mathrm{m}^{-3}$ & -0.61 & -0.05 & 0.25 & & & \\
\hline $\mathrm{CO} \mathrm{mg} \cdot \mathrm{m}^{-3}$ & -0.42 & 0.38 & 0.35 & 0.56 & & \\
\hline $\mathrm{NO}_{2} \mu \mathrm{g} \cdot \mathrm{m}^{-3}$ & 0.04 & -0.28 & 0.35 & 0.33 & 0.31 & \\
\hline $\mathrm{O}_{3} \mu \mathrm{g} \cdot \mathrm{m}^{-3}$ & 0.68 & -0.55 & -0.01 & -0.35 & -0.57 & 0.19 \\
\hline \multicolumn{7}{|c|}{ Cold season (October - March) } \\
\hline Humidity \% & 0.25 & & & & & \\
\hline Particles $\mu \mathrm{g} \cdot \mathrm{m}^{-3 *}$ & 0.16 & 0.02 & & & & \\
\hline $\mathrm{SO}_{2} \mu \mathrm{g} \cdot \mathrm{m}^{-3}$ & -0.51 & -0.23 & 0.26 & & & \\
\hline $\mathrm{CO} \mathrm{mg} \cdot \mathrm{m}^{-3}$ & 0.10 & 0.33 & 0.49 & 0.37 & & \\
\hline $\mathrm{NO}_{2} \mu \mathrm{g} \cdot \mathrm{m}^{-3}$ & 0.04 & -0.21 & 0.50 & 0.40 & 0.41 & \\
\hline $\mathrm{O}_{3} \mu \mathrm{g} \cdot \mathrm{m}^{-3}$ & 0.10 & -0.59 & -0.02 & -0.12 & -0.44 & 0.19 \\
\hline \multicolumn{7}{|c|}{ Warm season (April-September) } \\
\hline Humidity \% & -0.20 & & & & & \\
\hline Particles $\mu \mathrm{g} \cdot \mathrm{m}^{-3 *}$ & 0.10 & 0.07 & & & & \\
\hline $\mathrm{SO}_{2} \mu \mathrm{g} \cdot \mathrm{m}^{-3}$ & -0.27 & -0.34 & 0.25 & & & \\
\hline $\mathrm{CO} \mathrm{mg} \cdot \mathrm{m}^{-3}$ & -0.21 & 0.19 & 0.21 & 0.44 & & \\
\hline $\mathrm{NO}_{2} \mu \mathrm{g} \cdot \mathrm{m}^{-3}$ & -0.15 & -0.31 & 0.25 & 0.68 & 0.59 & \\
\hline $\mathrm{O}_{3} \mu \mathrm{g} \cdot \mathrm{m}^{-3}$ & 0.56 & -0.49 & 0.11 & 0.06 & -0.38 & 0.13 \\
\hline
\end{tabular}

*: suspended particles with a cut-off point at $\sim 13 \mu \mathrm{m}$. $\mathrm{SO}_{2}$ : sulphur dioxide; $\mathrm{CO}$ : carbon monoxide; $\mathrm{NO}_{2}$ : nitrogen dioxide; $\mathrm{O}_{3}$ : ozone.

to be higher in winter than in summer, whereas $\mathrm{O}_{3}$ was higher in the warm season. There was a certain degree of collinearity among the environmental variables, especially between $\mathrm{SO}_{2}$ and $\mathrm{CO}(\mathrm{r}=0.57), \mathrm{CO}$ and $\mathrm{O}_{3}$ $(\mathrm{r}=-0.54)$, and between particles and both $\mathrm{CO}$ $(\mathrm{r}=0.35)$ and $\mathrm{NO}_{2}(\mathrm{r}=0.35)$. Between-pollutant correlations were slightly different across seasons.

\section{Hospital admissions for respiratory conditions}

The Agency for Public Health of the Lazio Region routinely maintains records for all hospital admissions occurring in the region, which encompasses Rome and its surroundings. The information system has been fairly complete since January 1995 , covering $96 \%$ of both public and private hospitals in Lazio. The admissions occurring in Rome, January 1995-October 1997 ( $\sim 1.5$ million admissions) were selected first. Although the system does not permit a straightforward classification of emergency and elective admissions, conditions that were more likely to be unrelated to air pollution and/or elective were identified: dayhospital stay, rehabilitation, surgery, hospital transfers, traumas, deliveries, psychiatric and dermatological conditions, thus excluding about 775,000 admissions (56\% of the total). Daily counts of all respiratory conditions (International Classification of Diseases (ICD) 460-519, excluding 470-478), acute respiratory infections including pneumonia (ICD 460-466, 480-486), chronic obstructive pulmonary disease (COPD) (ICD 490-492,494-496) and asthma (ICD 493) among residents of all ages were then retrieved. In addition, hospital admissions for respiratory conditions, acute respiratory infections, and asthma occurring among children $(0-14$ yrs $)$ were also separately analysed. Hospitalization data for influenza
(ICD 487) were collected to control for viral respiratory seasonal epidemics. Primary diagnoses and the leading conditions requiring the most hospital care resources defined at discharge from the hospital, were considered.

\section{Data analysis}

To estimate the association between pollutants at different lags and hospital admissions, semiparametric Poisson regression was used. Generalized additive models [12] with correction for overdispersion were run using S-Plus4 (MathSoft, Seattle, WA, USA). The models included smooth functions of the day of study, mean temperature, mean humidity, daily number of hospital admissions for influenza, and indicator variables for day of the week and holidays. The analysis was conducted separately for all ages and for children. It had to be taken into account that the denominator (population present on a given day) of the Poisson variable (daily count) is not constant: there are fewer Rome residents actually present in the city during the summer period (especially during August) than during other seasons. Failure to consider changes in the denominator may lead to underestimation of the effects of summer pollutants, such as $\mathrm{O}_{3}$. Since a precise estimate of the population change by day was not available, all hospital admissions registered among residents of all ages (or in the $0-14$-yrs-old range) were considered as a proxy for the population denominator. To avoid overcontrol for the effect of pollution, rather than using the actual daily count, a spline smooth of the total admissions during the study period was used in the Poisson regression. For each year, such a smooth was a straight line from January to the middle of July, had 
a variable dip during August, and returned to a straight line from September through December. Although a sensitivity analysis indicated that the results were practically similar, this approach was more efficient to control changes in the denominator than including dummies for summer months or excluding those months from the analysis.

Spline smooths of time, mean temperature (at lag 1 ), and mean relative humidity (at lag 1) were used. The choice of the appropriate span was based on two criteria: minimization of the Akaike's Information Criterion, as well as on lack of over- or under-fitting in the residual correction for autocorrelation. Separate smooths for each end-point were fitted, although total respiratory conditions, and cause-specific analysis showed similar patterns: the degrees of freedom were 27 for time ( $\sim 1$ month), 9 for temperature (3 months), 3 for humidity (1 yr). One-day lag in both temperature and humidity was selected because they had the best combined fit.

After building the basic regression models of hospital admissions, single pollutants were entered as linear terms and the effects at lag $0,1,2,3$, and 4 were estimated. A possible effect modification by season of the relationship between pollutants and hospitalizations was evaluated introducing interaction terms into the regression models only for pollutants with a significant main effect. Multipollutant models were run for pollutants that were significant in the single pollutant analysis, and the lag that had the strongest univariate effect was tested. The results of the analysis were expressed as per cent increase in daily admissions with each increment of an interquartile range (IQR) of each pollutant, thus the magnitude of the estimates is comparable among pollutants.

\section{Results}

Table 1 summarizes the descriptive statistics of the hospital admissions. A daily average of 43.1 respiratory admissions, 11.3 among children, were observed in the study period, $>40 \%$ of the total respiratory admissions were from acute respiratory infections (with a higher proportion among children). An average of 13 COPD admissions and 4.5 asthma admissions per day were counted in all the population; 1.8 daily asthma admissions were recorded among children.

Total respiratory admissions were significantly associated with same-day level of $\mathrm{NO}_{2}(2.5 \%$ increase per IQR change $\left.22.3 \mu \mathrm{g} \cdot \mathrm{m}^{-3}\right)$, and $\mathrm{CO}(2.8 \%$ increase per IQR, $1.5 \mathrm{mg} \cdot \mathrm{m}^{-3}$ ) (table 3 ). The effect was also present at lag 1 and lag 2 for $\mathrm{NO}_{2}$, and at lag 1 for CO. No overall effect was detected for particles and $\mathrm{SO}_{2}$, whereas a nonsignificant association was observed for $\mathrm{O}_{3}$ at lag 1 (2.1\% increase per IQR, $\left.23.9 \mu \mathrm{g} \cdot \mathrm{m}^{-3}\right)$. The cause-specific analysis revealed that $\mathrm{NO}_{2}(4.0 \%$ increase, lag 0$)$ and $\mathrm{CO}(2.2 \%$ increase, lag $0)$ were associated with acute respiratory infections, and $\mathrm{CO}$ with both asthma (5.5\% increase, lag 0$)$ and COPD (4.3\% increase, lag 0). Examining the lag structure, there was no indication that the effects of air pollution were present at lags $>2$ days. All the effects were generally stronger during the warm

Table 3. - Per cent increase in daily hospital admissions for all ages per interquartile range (IQR) increase of pollutants at different lags (0-4), Rome 1995-1997

\begin{tabular}{|c|c|c|c|c|c|c|}
\hline Variable & Lag & $\begin{array}{c}\text { Particles } \\
\text { IQR: } 23.0 \mu \mathrm{g} \cdot \mathrm{m}^{-3}\end{array}$ & $\begin{array}{c}\mathrm{SO}_{2} \\
\text { IQR: } 6.9 \mu \mathrm{g} \cdot \mathrm{m}^{-3}\end{array}$ & $\begin{array}{c}\mathrm{NO}_{2} \\
\text { IQR: } 22.3 \mu \mathrm{g} \cdot \mathrm{m}^{-3}\end{array}$ & $\begin{array}{c}\mathrm{CO} \\
\text { IQR: } 1.5 \mathrm{mg} \cdot \mathrm{m}^{-3}\end{array}$ & $\begin{array}{c}\mathrm{O}_{3} \\
\text { IQR: } 23.9 \mu \mathrm{g} \cdot \mathrm{m}^{-3}\end{array}$ \\
\hline \multicolumn{7}{|l|}{ Respiratory conditions } \\
\hline \multirow[t]{5}{*}{ (ICD-IX: $460-519)$} & 0 & $0.2(-1.0-1.4)$ & $0.4(-1.3-2.2)$ & $2.5(0.9-4.2)$ & $2.8(1.3-4.3)$ & $0.3(-2.0-2.6)$ \\
\hline & 1 & $-1.1(-2.3-0.1)$ & $0.8(-0.9-2.4)$ & $1.8(0.2-3.4)$ & $1.8(0.2-3.3)$ & $2.1(-0.4-4.7)$ \\
\hline & 2 & $-0.3(-1.5-1.0)$ & $0.3(-1.3-1.8)$ & $1.8(0.3-3.4)$ & $0.2(-1.3-1.8)$ & $0.4(-1.9-2.7)$ \\
\hline & 3 & $-0.5(-1.7-0.7)$ & $0.4(-1.1-1.9)$ & $0.6(-0.9-2.2)$ & $-0.5(-2.0-1.1)$ & $1.7(-0.5-4.0)$ \\
\hline & 4 & $0.5(-0.7-1.8)$ & $0.9(-0.7-2.4)$ & $0.7(-0.8-2.2)$ & $0.7(-0.8-2.2)$ & $1.2(-1.0-3.4)$ \\
\hline \multicolumn{7}{|l|}{ Acute respiratory } \\
\hline infections & 0 & $0.4(-1.3-2.2)$ & $0.4(-2.1-3.0)$ & $4.0(1.6-6.5)$ & $2.2(0.0-4.4)$ & $2.7(-0.6-6.1)$ \\
\hline \multirow{4}{*}{ (ICD-IX: $460-466 ; 480-486)$} & 1 & $-0.9(-2.7-0.8)$ & $1.4(-1.0-3.9)$ & $2.2(-0.1-4.5)$ & $2.1(-0.1-4.4)$ & $3.2(-0.5-7.0)$ \\
\hline & 2 & $-0.1(-1.8-1.7)$ & $1.2(-1.0-3.5)$ & $3.0(0.8-5.3)$ & $1.7(-0.5-4.0)$ & $2.6(-0.7-6.0)$ \\
\hline & 3 & $-1.2(-2.9-0.6)$ & $0.2(-1.9-2.5)$ & $1.1(-1.1-3.3)$ & $-0.9(-3.0-1.3)$ & $2.2(-1.0-5.5)$ \\
\hline & 4 & $-0.4(-2.2-1.4)$ & $0.7(-1.5-2.9)$ & $0.7(-1.5-3.0)$ & $1.5(-0.7-3.7)$ & $-0.3(-3.4-2.8)$ \\
\hline 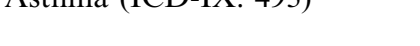 & 0 & $-2.2(-5.8-1.5)$ & $-1.5(-6.6-3.9)$ & $4.6(-0.5-10.0)$ & $5.5(0.9-10.4)$ & $3.8(-3.0-11.0)$ \\
\hline & 1 & $-2.1(-5.7-1.7)$ & $-1.5(-6.5-3.7)$ & $4.3(-0.5-9.4)$ & $0.8(-3.8-5.7)$ & $4.0(-3.6-12.2)$ \\
\hline & 2 & $-1.3(-4.9-2.5)$ & $2.5(-2.2-7.4)$ & $4.6(-0.1-9.6)$ & $-1.3(-5.9-3.5)$ & $4.2(-2.7-11.6)$ \\
\hline & 3 & $-0.5(-4.2-3.3)$ & $-1.3(-5.9-3.5)$ & $1.5(-3.1-6.3)$ & $-3.0(-7.4-1.6)$ & $3.9(-2.8-11.0)$ \\
\hline & 4 & $-2.0(-5.6-1.8)$ & $-1.2(-5.7-3.5)$ & $3.0(-1.6-7.9)$ & $0.6(-4.0-5.3)$ & $3.8(-2.8-10.8)$ \\
\hline \multicolumn{7}{|l|}{ COPD } \\
\hline (ICD-IX: 490-492; 494-496) & 0 & $1.8(-0.3-4.0)$ & $1.0(-1.9-4.0)$ & $2.2(-0.7-5.2)$ & $4.3(1.6-7.1)$ & $-3.4(-7.2-0.6)$ \\
\hline & 1 & $1.0(-1.1-3.2)$ & $-1.1(-3.9-1.8)$ & $-1.1(-3.8-1.7)$ & $-0.2(-2.9-2.5)$ & $3.6(-0.9-8.3)$ \\
\hline & 2 & $1.2(-1.0-3.4)$ & $-0.5(-3.1-2.1)$ & $-0.5(-3.2-2.2)$ & $-0.2(-2.9-2.6)$ & $-3.3(-7.1-0.7)$ \\
\hline & 3 & $1.1(-1.1-3.3)$ & $1.4(-1.2-4.0)$ & $-0.4(-3.1-2.4)$ & $-0.3(-3.0-2.4)$ & $1.3(-2.6-5.4)$ \\
\hline & 4 & $1.5(-0.7-3.7)$ & $2.0(-0.7-4.7)$ & $-0.7(-3.3-2.1)$ & $-0.1(-2.8-2.6)$ & $2.5(-1.4-6.5)$ \\
\hline
\end{tabular}

Data presented as per cent increase (95\% confidence interval). COPD: chronic obstructive pulmonary disease; $\mathrm{SO}_{2}$ : sulphur dioxide; $\mathrm{NO}_{2}$ : nitrogen dioxide; $\mathrm{CO}$ : carbon monoxide; $\mathrm{O}_{3}$ : ozone. 
Table 4.-Per cent (\%) increase in daily hospital admissions for the $0-14$ yrs age range per interquartile range (IQR) increase of pollutants at different lags (0-4), Rome 1995-1997

\begin{tabular}{|c|c|c|c|c|c|c|}
\hline Variable & Lag & $\begin{array}{c}\text { Particles } \\
\text { IQR: } 23.0 \mu \mathrm{g} \cdot \mathrm{m}^{-3}\end{array}$ & $\begin{array}{c}\mathrm{SO}_{2} \\
\text { IQR: } 6.9 \mu \mathrm{g} \cdot \mathrm{m}^{-3}\end{array}$ & $\begin{array}{c}\mathrm{NO}_{2} \\
\text { IQR: } 22.3 \mu \mathrm{g} \cdot \mathrm{m}^{-3}\end{array}$ & $\begin{array}{c}\mathrm{CO} \\
\text { IQR: } 1.5 \mathrm{mg} \cdot \mathrm{m}^{-3}\end{array}$ & $\begin{array}{c}\mathrm{O}_{3} \\
\text { IQR: } 23.9 \mu \mathrm{g} \cdot \mathrm{m}^{-3}\end{array}$ \\
\hline \multicolumn{7}{|l|}{ Respiratory conditions } \\
\hline \multirow[t]{4}{*}{ (ICD-IX: $460-519)$} & $\begin{array}{l}0 \\
1\end{array}$ & $\begin{array}{r}0.2(-2.2-2.6) \\
-0.7(-3.0-1.7)\end{array}$ & $\begin{array}{l}-0.7(-4.0-2.7) \\
-2.0(-5.2-1.3)\end{array}$ & $\begin{array}{l}4.0(0.6-7.5) \\
2.0(-1.2-5.3)\end{array}$ & $\begin{array}{l}2.5(-0.3-5.5) \\
0.8(-2.1-3.8)\end{array}$ & $\begin{array}{l}3.3(-1.3-8.1) \\
5.4(0.2-10.9)\end{array}$ \\
\hline & 2 & $-1.7(-4.0-0.6)$ & $-0.8(-3.8-2.3)$ & $2.3(-0.9-5.5)$ & $0.2(-2.7-3.1)$ & $2.5(-2.1-7.3)$ \\
\hline & 3 & $0.4(-1.9-2.8)$ & $-1.9(-4.8-1.1)$ & $2.1(-1.0-5.3)$ & $-1.0(-3.7-1.9)$ & $2.0(-2.5-6.6)$ \\
\hline & 4 & $1.7(-0.6-4.2)$ & $-0.2(-3.0-2.8)$ & $0.6(-2.4-3.8)$ & $3.2(0.4-6.2)$ & $0.8(-3.5-5.3)$ \\
\hline \multicolumn{7}{|l|}{ Acute respiratory } \\
\hline & 0 & $1.3(-1.4-4.1)$ & $-0.1(-3.9-3.8)$ & $4.0(0.2-8.0)$ & $2.5(-0.8-5.8)$ & $5.0(-0.3$ \\
\hline \multirow[t]{4}{*}{ (ICD-IX: $460-466 ; 480-486)$} & 1 & $-0.6(-3.3-2.1)$ & $-2.7(-6.3-1.0)$ & $1.0(-2.5-4.6)$ & $-0.1(-3.4-3.2)$ & $8.1(2.1-14.4)$ \\
\hline & 2 & $-1.0(-3.6-1.7)$ & $-1.2(-4.5-2.2)$ & $2.7(-0.9-6.3)$ & $0.9(-2.3-4.3)$ & $4.3(-1.0-9.9)$ \\
\hline & 3 & $0.7(-1.9-3.5)$ & $-2.5(-5.7-0.9)$ & $2.5(-1.0-6.2)$ & $-2.0(-5.1-1.2)$ & $4.9(-0.2-10.3)$ \\
\hline & 4 & $2.2(-0.5-5.0)$ & $0.0(-3.2-3.3)$ & $1.2(-2.2-4.8)$ & $3.2(0.0-6.6)$ & $2.8(-2.2-8.0)$ \\
\hline AstmIIa (ICD-1A. 49 & 0 & $-2.2(-7.5-3.5)$ & $-2.6(-10.4-6.0)$ & $6.4(-1.4$ & $6.3(-0.5$ & $-1.6(-11.3-9.1)$ \\
\hline & 1 & $-2.2(-7.5-3.5)$ & $4.3(-3.5-12.7)$ & $10.7(3.0-19.0)$ & $8.2(1.1-15.7)$ & $0.2(-10.8-12.5)$ \\
\hline & 2 & $-4.0(-9.2-1.6)$ & $5.5(-1.8-13.2)$ & $5.5(-1.8-13.3)$ & $-0.7(-7.3-6.3)$ & $5.6(-5.0-17.2)$ \\
\hline & 3 & $3.5(-2.2-9.4)$ & $2.8(-4.2-10.4)$ & $2.3(-4.8-9.9)$ & $3.5(-3.2-10.6)$ & $-1.8(-11.3-8.7)$ \\
\hline & 4 & $0.4(-5.1-6.3)$ & $1.0(-5.9-8.3)$ & $-0.4(-7.3-7.0)$ & $4.8(-1.9-12.0)$ & $-1.8(-11.2-8.6)$ \\
\hline
\end{tabular}

Data presented as per cent increase (95\% confidence interval). $\mathrm{SO}_{2}$ : sulphur dioxide; $\mathrm{NO}_{2}$ : nitrogen dioxide; CO: carbon monoxide; $\mathrm{O}_{3}$ : ozone.

season, but the interaction terms were significant only for $\mathrm{CO}$. $\mathrm{CO}$ at lag 0 was associated with a $10.8 \%$ increase (per IQR) (95\% confidence interval (CI): $6.7-14.8)$ in total respiratory admissions, an $8.6 \%$ increase in acute respiratory infections $(95 \% \mathrm{CI}$ : $2.9-14.6$ ), and $13.9 \%$ increase in COPD admissions (95\% CI: $6.8-21.5)$.

Among children, total respiratory admissions were associated with $\mathrm{NO}_{2}(4.0 \%$ increase, lag 0$)$ and with $\mathrm{O}_{3}\left(5.4 \%\right.$ increase, lag 1) (table 4). $\mathrm{O}_{3}$ had a strong effect on acute respiratory conditions $(8.1 \%$ increase, lag 1) while $\mathrm{NO}_{2}$ was strongly associated with asthma admissions (10.7\% increase, lag 1$)$. CO was also associated with asthma $(8.2 \%$ increase, lag 1$)$. As among the entire population, no effect of particles or of $\mathrm{SO}_{2}$ was detected. Moreover, no effect was found at lag 3 or 4 and no significant effect modification by season was detected.

Table 5 presents a summary of the main findings (single pollutant models) as well as the results of the multipollutant models. The associations between the pollutants and the outcomes were generally weaker and more unstable in multipollutant models than in univariate regressions. However, $\mathrm{CO}$ was the single pollutant associated with all respiratory admissions, asthma and COPD. $\mathrm{NO}_{2}$ had a stronger effect than $\mathrm{CO}$ on acute respiratory infections (table 5). Conversely, among children $\mathrm{NO}_{2}$ and $\mathrm{O}_{3}$ lost statistical significance when both were present in the same model for all respiratory conditions and asthma. However, $\mathrm{O}_{3}$ remained associated with acute respiratory infections even when adjusting for $\mathrm{NO}_{2}$.

\section{Discussion}

Current air pollution in Rome is associated with increased respiratory hospital admissions. Single and multipollutant models suggested that $\mathrm{CO}, \mathrm{NO}_{2}$, and
$\mathrm{O}_{3}$ are important contributors to respiratory hospitalization. In particular, $\mathrm{CO}$ plays a major role for admissions among adults whereas $\mathrm{NO}_{2}$ and $\mathrm{O}_{3}$ seem to be indicators of acute respiratory problems in children. The effects of air pollutants, at least that of $\mathrm{CO}$, seem to be stronger during the warm season. In this study, as in other investigations on air pollution and hospital admissions, it is difficult to separate the role of each factor because of collinearity among pollutants which makes the risk estimates unstable. For this reason, there is some controversy regarding the use of multipollutant modelling in air pollution research, but not a single solution has proved optimal [13].

In 1991, SUNYER et al. [14] reported one of the first time-series analyses of daily air pollution and daily emergency hospital admissions for COPDs in Barcelona, a high density Mediterranean city in which motor vehicles are the most important source of pollution. They found a positive association between admissions for obstructive pulmonary disease and black smoke, $\mathrm{SO}_{2}$ and $\mathrm{CO}$. In the same year, PonKA [15] found that $\mathrm{NO}_{2}, \mathrm{O}_{3}$, and $\mathrm{CO}$ were strongly associated with emergency room visits and hospital admissions for asthma in Helsinki. Subsequent studies in the USA and Canada have focused on particles and $\mathrm{O}_{3}$ as the key pollutants associated with emergency room visits or hospital admissions for respiratory conditions and asthma [16-21]. However, European time-series analyses conducted mostly within the Air Pollution on Health, European Approach (APHEA) initiative [22] have suggested that gaseous air pollutants are more important determinants of acute hospitalization for respiratory conditions than particulate mass. Three quantitative summaries of the APHEA city-specific results have evaluated the relationship between various pollutants (particles, either black smoke or total suspended particulates 
Table 5. - Per cent (\%) increase in daily hospital admissions per interquartile range (IQR) increase of pollutants in single and multipollutant models, Rome 1995-1997

\begin{tabular}{|c|c|c|c|c|}
\hline Variable & ICD No. & Lag & Single pollutant model* & Multipollutant model** \\
\hline \multicolumn{5}{|l|}{ All ages } \\
\hline Respiratory conditions & $460-519$ & & & \\
\hline $\mathrm{NO}_{2}$ & & 0 & $2.5(0.9-4.2)$ & $0.9(-0.8-2.8)$ \\
\hline $\mathrm{CO}$ & & 0 & $2.8(1.3-4.3)$ & $2.3(0.6-4.0)$ \\
\hline Acute respiratory infections & $460-466 ; 480-486$ & & & \\
\hline $\mathrm{NO}_{2}$ & & 0 & $4.0(1.6-6.5)$ & $3.9(1.3-6.7)$ \\
\hline $\mathrm{CO}$ & & 0 & $2.2(0.0-4.4)$ & $0.0(-2.3-2.4)$ \\
\hline Asthma & 493 & & & \\
\hline $\mathrm{NO}_{2}$ & & 0 & $4.6(-0.5-10.0)$ & $1.4(-3.9-7.1)$ \\
\hline $\mathrm{CO}$ & & 0 & $5.5(0.9-10.4)$ & $4.8(0.3-9.5)$ \\
\hline COPD & $490-492 ; 494-496$ & & & \\
\hline $\mathrm{NO}_{2}$ & & 0 & $2.2(-0.7-5.2)$ & $-1.0(-4.1-2.2)$ \\
\hline $\mathrm{CO}^{-}$ & & 0 & $4.3(1.6-7.1)$ & $4.8(0.9-7.9)$ \\
\hline \multicolumn{5}{|l|}{$0-14$ yrs } \\
\hline Respiratory conditions & $460-519$ & & & \\
\hline $\mathrm{NO}_{2}$ & & 0 & $4.0(0.6-7.5)$ & $3.3(-0.2-6.9)$ \\
\hline $\mathrm{CO}$ & & 1 & $5.4(0.2-10.9)$ & $4.1(-1.2-9.8)$ \\
\hline Acute respiratory infections & $460-466 ; 480-486$ & & & \\
\hline $\mathrm{NO}_{2}$ & & 0 & $4.0(0.2-8.0)$ & $2.9(-1.0-7.0)$ \\
\hline $\mathrm{CO}$ & & 1 & $8.1(2.1-14.4)$ & $6.9(0.8-13.4)$ \\
\hline Asthma & 493 & & & \\
\hline $\mathrm{NO}_{2}$ & & 1 & $10.7(3.0-19.0)$ & $8.3(-0.1-17.4)$ \\
\hline $\mathrm{CO}^{2}$ & & 1 & $8.2(1.1-15.7)$ & $3.3(-4.2-11.3)$ \\
\hline
\end{tabular}

Data presented as per cent increase ( $95 \%$ confidence interval). *: single pollutant model results for the most significant single day lag; **: estimates from regression models containing the two pollutants indicated in the rows simultaneously. $\mathrm{NO}_{2}$ : nitrogen dioxide; $\mathrm{CO}$ : carbon monoxide; $\mathrm{O}_{3}$ : ozone; $\mathrm{COPD}$ : chronic obstructive pulmonary disease.

(TSP), $\mathrm{SO}_{2}, \mathrm{NO}_{2}$, and $\mathrm{O}_{3}$ ) and total respiratory hospital admissions in five cities [7], admissions for COPD in six cities [6], and emergency admissions for asthma in four cities [8]. The most consistent finding for total respiratory conditions and COPD was the association with $\mathrm{O}_{3}$. The association with particles was considerably smaller than in North American studies, whereas $\mathrm{NO}_{2}$ was associated with COPD but not with total respiratory conditions (although a black smoke effect was detected only in the presence of high $\mathrm{NO}_{2}$ levels). The results for asthma were more controversial and less consistent since positive associations with particles, $\mathrm{SO}_{2}$, and $\mathrm{NO}_{2}$ were found, but not in all age groups and cities [8, 23].

More recent investigations have underlined the importance of $\mathrm{NO}_{2}$ and $\mathrm{CO}$. An investigation in Valencia, Spain, found an association between asthma admissions and $\mathrm{NO}_{2}$ and $\mathrm{O}_{3}$ but not with black smoke and $\mathrm{SO}_{2}$ [24]. A report from Sydney, Australia highlighted $\mathrm{NO}_{2}$ as the single pollutant related to childhood asthma admissions [9]. The analysis of the association between outdoor pollutants and visits to emergency departments for respiratory complaints in London [25] revealed a strong relationship between $\mathrm{NO}_{2}$ levels and asthma visits by children, especially during the warm season. The same study found an association between $\mathrm{CO}$ and daily visits for respiratory complaints among the elderly. A parallel analysis of daily general practitioner consultations for asthma and other lower respiratory conditions in London showed stronger effects for $\mathrm{NO}_{2}, \mathrm{CO}$, and $\mathrm{SO}_{2}$ in children and PM10 in adults [26]. In Seattle, (WA, USA) $\mathrm{CO}$ and PM10 were found to be jointly associated with hospital asthma admissions among the nonelderly [27] and with asthma emergency room visits by children [28].

From the evidence reviewed earlier, it seems that pollutants, either primarily generated by combustion sources or secondarily produced after chemical transformation in the atmosphere, aggravate preexisting chronic respiratory conditions, such as COPD or asthma, or precipitate acute respiratory infections of the upper or lower respiratory tract. Fine and ultrafine particles from combustion sources are the most likely causes of the respiratory effects, given the evidence from the American panel studies [3, 29]. In the absence of detailed measurements of fine and ultrafine particles, however, it is extremely diffficult to single out the precise pollutant or combination of pollutants, which are specifically responsible for the health effects described. There are several possible explanations for the inconsistent results of the various studies. 1) The concentration of pollutants in a single city correlate, with varying degrees, to meteorological conditions during the year. 2) Climatic and geographical conditions vary between cities, rendering the air pollution mix different. 3) The accuracy of pollutant measurements (i.e. number of monitoring sites, location of monitors, frequency of measurements, particle size measured) may vary from one location to another. 4) The prevalence of conditions, such as COPD or asthma, may vary widely from one country to another and the proportion of the susceptible population may be different. For instance, asthma among children is at least three times more prevalent in the UK and Ireland than in Mediterranean 
countries like Spain and Italy [30]. The reason why the European studies seem to show more $\mathrm{NO}_{2} / \mathrm{CO}$ effects than US studies is to be explored. It may be that $\mathrm{NO}_{2} /$ $\mathrm{CO}$ are better surrogates for ultrafine particles in Europe than in the USA because of different combustion sources (greater use of diesel in Europe).

The present study did not find a specific effect of particles as they were measured in Rome during the study period. From an exposure assessment point of view, it should be stressed that particles had the larger spatial within-day variability and, therefore, the larger error in the daily level of exposure. These negative findings may be attributable to this limitation. In addition, particle measurements for the study period do not accurately reflect the concentration of fine particles. In fact, particulate pollution in Rome is strongly influenced by local traffic during winter months, while it is more dependent on secondary transformations and on long-range transport (including coarse particles, that is particles with a $50 \%$ cutoff aerodynamic diameter between 10 and $2.5 \mu \mathrm{m}$ ) during the warm period. Preliminary investigations in the city indicate that the coarse/fine particles ratio ((PM10-PM2.5)/PM2.5) is seasonally dependent $(0.68$ in winter, 0.97 in summer) with a higher concentration of coarse particles during the warm period [31]. Conversley, $\mathrm{CO}$ and $\mathrm{NO}_{2}$ are better markers of air pollution directly related to traffic.

The studies within the APHEA projects did not include $\mathrm{CO}$, a primary pollutant related to traffic. However, as the initial studies from Barcelona [14] and Helsinki [15] had suggested, $\mathrm{CO}$ has been related to respiratory hospitalizations in 16 Canadian cities [32], and to asthma hospital admissions among nonelderly residents in Seattle [27]. In the present study, CO showed an association with most of the respiratory conditions in all ages studied, and its independent role remained in the multipollutant analysis for total admissions. The simplest explanation for the association found is that $\mathrm{CO}$ is a good marker of the pollution mix in winter (including primary fine and ultrafine particles). In fact, a close correlation between $\mathrm{CO}$ and fine particles measurements has recently been detected in Seattle [28]. A recent study from Norway has suggested that benzene concentration, an indicator of air traffic pollution closely linked with $\mathrm{CO}$, was the most important predictor among eight pollutants in ambient air (excluding $\mathrm{CO}$ ) of respiratory hospital admissions [33]. However, since CO has recently been associated with emergency cardiovascular hospitalizations [34], in particular ischaemic heart disease [35], and as there are novel insights into its biological effects at low levels such as release of NO by endothelial cells [36], a more careful examination of the role of this pollutant in the respiratory tract would be worthwhile.

Apart from the analysis of emergency admissions for asthma, only a few studies have addressed the overall acute respiratory effects of air pollution among children, in particular the association with acute respiratory infections. The present study found an association between photochemical pollutants (both ozone and nitrogen dioxide) and hospitalizations for acute respiratory infections, especially in children. Ozone and nitrogen dioxide concentrations are clearly related since ozone plays a primary role in the conversion of nitric oxide to nitrogen dioxide, even during winter. The health effects of ozone are well known: it causes an increase in respiratory symptoms such as cough and shortness of breath, reduced lung function, and inflammatory response from the airway mucosa [16]. Conversely, toxicological evidence [37] suggests that nitrogen dioxide increases the susceptibility to infection by viruses and bacteria, while a preliminary epidemiological study has indicated that personal exposure to nitrogen dioxide increases the risk of virus related asthma morbidity in children [38]. The results presented here may indicate that the inflammatory response to infections is altered by exposure to oxidants (and perhaps by exposure to fine particles [38 -39]) thus leading to aggravation of symptoms and increasing the number of infection-related hospital admissions.

\section{References}

1. Environmental Protection Agency. Air Quality Criteria for Particulate Matter. Washington, DC, USA. Environmental Protection Agency, 1996. EPA/600/ P-95/001 cF.

2. Bates CV, Sizto R. Air pollution and hospital admissions in Southern Ontario: the acid summer haze effect. Environ Res 1987; 43: 317-331.

3. Dockery DW, Pope CA III. Acute respiratory effects of particulate air pollution. Ann Rev Public Health 1994; 15: $107-132$.

4. Moolgavkar SH, Luebeck EG, Anderson EL. Air pollution and hospital admissions for respiratory causes in Minneapolis-St. Paul and Birmingham. Epidemiology 1997; 8: $364-370$.

5. Burnett RT, Cakmak S, Brook JR, Krewski D. The role of particulate size and chemistry in the association between summertime ambient air pollution and hospitalization for cardiorespiratory diseases. Environ Health Perspect 1997; 105: 614-620.

6. Anderson HR, Spix C, Medina S, et al. Air pollution and daily admissions for chronic obstructive pulmonary disease in 6 European cities: results from the APHEA project. Eur Respir J 1997; 10: 1064-1071.

7. Spix C, Anderson HR, Schwartz J, et al. Short-term effects of air pollution on hospital admissions of respiratory diseases in Europe: a quantitative summary of APHEA study results. Arch Environ Health 1998; 53: 54-64.

8. Sunyer J, Spix C, Quénel P, et al. Urban air pollution and emergency admissions for asthma in four European cities: the APHEA project. Thorax 1997; 52: $760-765$.

9. Morgan G, Corbett S, Wlodarczyk J. Air pollution and hospital admissions in Sydney, Australia, 1990 to 1994. Am J Public Health 1998; 88: $1761-1766$.

10. Michelozzi P, Forastiere F, Fusco D, et al. Air pollution and daily mortality in Rome, Italy. Occup Environ Med. 1998; 55: 605-610.

11. Brook JR, Dann TF, Burnett RT. The relationship among TSP, PM10, PM2.5, and inorganic constituents of atmospheric particulate matter at multiple Canadian locations. J Air Waste Manag Assoc 1997; 47: 2-19. 
12. Hastie T, Tibshirani R. Generalized Additive Models. London, Chapman and Hall, 1990.

13. Pitard A, Viel JF. Some methods to address collinearity among pollutants in epidemiological time series. Stat Med 1997; 16: 527-544.

14. Sunyer J, Anto JM, Murillo C, Saez M. Effects of urban air pollution on emergency room admissions for chronic obstructive pulmonary disease. Am J Epidemiol 1991; 134: 277-286.

15. Ponka A. Asthma and low level air pollution in Helsinki. Arch Environ Health 1991; 46: 262-270.

16. Health effects of outdoor air pollution. Committee of the Environmental and Occupational Health Assembly of the American Thoracic Society. Am J Respir Crit Care Med 1996; 153: 3-50.

17. Schwartz J. Air pollution and hospital admissions for the elderly in Birmingham, Alabama. Am J Epidemiol 1994; 139: 589-598.

18. Schwartz J. Air pollution end hospital admissions for the elderly in Detroit, Michigan. Am J Resp Crit Care Med 1994; 150: 648-655.

19. Schwartz J. PM10, ozone and hospital admissions for the elderly in Minneapolis-St Paul, Minnesota. Arch Environ Health 1994; 49: 366 - 374.

20. Burnen RT, Dales R, Kreuski D, Vincent R, Dann T, Brook JR. Associations between ambient particulate sulfate and admissions to Ontario hospitals for cardiac and respiratory diseases. Am J Epidemiol 1995; 142: $15-22$.

21. Schwartz J. Air pollution and hospital admissions for respiratory disease. Epidemiology 1996; 7: 20-28.

22. Katsouyanni K, Schwartz J, Spix C, et al. Short term effects of air pollution on health: a European approach using epidemiologic time series data: the APHEA protocol. J Epidemiol Community Health 1996; 50: Suppl. 1, S12-58.

23. Anderson HR, Ponce de Leon A, Bland JM, Bower JS, Emberlin J, Strachan DP. Air pollution, pollens, and daily admission for asthma in London 19871992. Thorax 1998; 53: $842-848$.

24. Tenias JM, Ballester F, Rivera ML. Association between hospital emergency visits for asthma and air pollution in Valencia, Spain. Occup Environ Med 1998; 55: $541-547$.

25. Atkinson RW, Anderson HR, Strachan DP, Bland JM, Bremner SA, Ponce de Leon A. Short-term associations between outdoor air pollution and visits to accident and emergency departments in London for respiratory complaints. Eur Respir J 1999; 13: 257 265.

26. Hajat S, Haines A, Goubet SA, Atkinson RW, Anderson HR. Association of air pollution with daily GP consultations for asthma and other lower respiratory conditions in London. Thorax 1999; 54: $597-605$.

27. Sheppard L, Levy D, Norris G, Larson TV, Koenig JQ. Effects of ambient air pollution on nonelderly asthma hospital admissions in Seattle, Washington, 1987-1994. Epidemiology 1999; 10: 23-30.

28. Norris G, YoungPong SN, Koenig JQ, Larson TV, Sheppard L, Stout JW. An association between fine particles and asthma emergency department visits for children in Seattle. Environ Health Perspect 1999; 107: 489-493.

29. Peters A, Wichmann HE, Tuch T, Heinrich J, Heyder J. Respiratory effects are associated with the number of ultrafine particles. Am J Respir Crit Care Med 1997; 155: $1376-1383$.

30. Anonymous. Worldwide variation in prevalence of symptoms of asthma, allergic rhinoconjuntivitis, and atopic eczema: ISAAC. The International Study of Asthma and Allergies in Childhood (ISAAC) Steering Committee. Lancet. 1998; 351: 1225-1232.

31. D'Innocenzio F, Di Filippo P, Lepore L, Marconi A. PM10 and PM2.5 concentrations in urban air and size fraction distribution of toxic metals. Ann Chim 1998; 88: $281-289$.

32. Burnett RT, Brook JR, Yung WT, Dales RE, Krewski D. Association between ozone and hospitalization for respiratory diseases in 16 Canadian cities. Environ Res 1997; 72: 24-31.

33. Hagen JA, Nafstad P, Skrondal A, Bjoerkly S, Magnus P. Associations between outdoor air pollutants and hospitalization for respiratory diseases. Epidemiology 2000; 11: 136-140.

34. Schwartz J. Air pollution and hospital admissions for heath disease in eight U.S. counties. Epidemiology 1999; 10: 17-22.

35. Poloniecki JD, Atkinson RW, de Leon AP, Anderson HR. Daily time series for cardiovascular hospital admissions and previous day's air pollution in London, UK. Occup Environ Med 1997; 54: 535-540.

36. Thom SR, Xu YA, Ischiropoulos H. Vascular endothelial cells generate peroxynitrite in response to carbon monoxide exposure. Chem Res Toxicol 1997; 10: $1023-1031$

37. Chauhan AJ, Krishna MT, Frew AJ, Holgate ST. Exposure to nitrogen dioxide $\left(\mathrm{NO}_{2}\right)$ and respiratory disease risk. Rev Environ Health 1998; 13: 73 -90.

38. Chauhan AJ, Linaker $\mathrm{CH}$, Inskip $\mathrm{H}$, et al. Personal exposure to nitrogen dioxide $\left(\mathrm{NO}_{2}\right)$ and the risk of virus related asthma morbidity. Am J Respir Crit Care Med 1992; 159: A699.

39. Becker S, Soukup JM. Exposure to urban air particulates alters the macrophage-mediated inflammatory response to respiratory viral infection. $J$ Toxicol Environ Health 1999; 13: 445-457. 